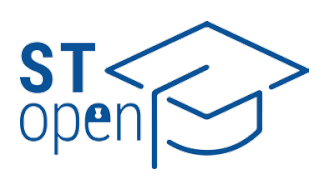

(c) 2021 The Author(s)

ST-OPEN @ 202

\title{
Forensic investigation of a mass grave at Ovčara, near Vukovar, of victims killed by the Serbian army in 1991
}

\author{
Helena Ekštajn (D), \\ Ivana Kružić (1), \\ Željana Bašić (1)
}

University of Split, University Department of Forensic Sciences, Split, Croatia

Correspondence to:

Helena Ekštajn

University Department of Forensic Sciences, University of Split, Ruđera Boškovića 33,

21000 Split, Croatia

helena.ekstajn@gmail.com

Cite as:

Ekštajn H, Kružić I, Bašić Ž. Forensic investigation of a mass grave at Ovčara, near Vukovar, of victims killed by the Serbian army in 1991. ST-OPEN. 2021; 2: e2021.2013.35.

https://doi.org/10.48188/so.2.3
Objective: To evaluate the contribution of forensic research to the discovery and analysis of mass graves of victims of the Yugoslav People's Army and Serbian paramilitaries at Ovčara, near Vukovar, and to the identification of exhumed victims as missing persons who were forcibly removed from Vukovar Hospital on 20 November 1991.

Methods: We analysed official international documentation and transcripts from the International Criminal Tribunal for the former Yugoslavia. Data on causes of death and injury classifications were derived from autopsy reports and their interpretation by a forensic specialist. Identification of individuals was based on a report by a representative of the Commission on Detainees and Missing Persons.

Results: Scientific and expert evidence from forensic research of the Ovčara mass grave shows that 198 male and 2 female bodies (one of a pregnant woman) in civilian clothes were exhumated from the site, with an average age of 32.5 years, including 3 minors. The determined manner of death for all 200 exhumed bodies was homicide, and the cause of death for $95 \%$ of the victims was a gunshot wound to a vital part of the body, in $67 \%$ of cases to the head. Traces of medical treatment and hospital workwear were found on 53\% of the victims. $96 \%$ of the bodies were positively identified, $46.5 \%$ using classical forensic methods, and $49.5 \%$ by DNA analysis. Most of the victims were Croatian nationals of the Catholic faith.

Conclusion: Forensic analysis and identification confirmed that the war crime victims exhumed from the Ovčara mass grave were listed as missing persons who disappeared from Vukovar Hospital. Their murder was used as relevant evidence of planned ethnic cleansing in court. 


\section{Introduction}

This paper describes how evidence-based forensic research and documentation was used to put these war crimes into historical context. It is a review of the official documentation used in the legal process. The analysis confirms that the victims buried in the Ovčara mass grave were not killed in military operations but were victims of a planned execution [1].

\section{Historical background}

When Croatia declared independence on 25 June 1991, its Serb minority openly renounced the authority of the newly proclaimed state. In August 1990, the rebellion started, and in 1991, backed by the Serb-dominated Yugoslav People's Army (YPA, in Croatian: Jugoslavenska narodna armija) and Serbian authorities, the insurgents declared an independent Serbian state covering one-third of Croatia's territory, intending to carry out systematic ethnic cleansing of Croats and other non-Serbian populations. From mid-1991, almost the entire territory of the Republic of Croatia was affected by heavy fighting. The UN decision to send international troops to monitor the occupied regions in early 1992 testifies to the scale of the destruction, including the nonselective shelling of Dubrovnik and Vukovar. In two major offensives in 1995, the Croatian army liberated most of the occupied territory; Eastern Slavonia, Western Srijem and Baranja were restored to Croatian rule by peaceful reintegration as late as 1998 [2, 3]. The war of aggression strategically relied on the concept of forming a 'Greater Serbia' and aimed to seize parts of Croatian territory and place them permanently under the rule of Serbia (at that time part of the Socialist Federal Republic of Yugoslavia along with Montenegro). Countless crimes were committed in the war of aggression, including the murder of civilians and prisoners, torture, rape, and expulsion [4]. Consciously and deliberately, international human rights were violated, many villages and towns were destroyed, and the victims of the killings were secretly buried in individual and mass graves [5]. Based on data available from official records of the Directorate for Detainees and Missing Persons of the Ministry of Croatian Veterans, 1,300 individual and 150 mass graves have been exhumed, $48 \%$ of which are on the Croatian side of the Danube region. As many as 5,181 bodies have been exhumed: $83.1 \%$ of these have been identified, $77.4 \%$ as victims of the 1991 crimes [6]. According to the official figures from the Directorate for Detainees and Missing Persons, 1,869 people who disappeared in the Homeland War are still missing [6].

The systematic nature of ethnic cleansing carried out in Croatia is reflected in the socio-demographic structure of identified victims from mass graves, in which $61 \%$ of individuals were identified as nonmilitary, 28\% were women, 36 persons were minors (under 18), and $39 \%$ were elderly. Most victims (almost 87\%) were Croatians [7].

\section{The devastation of Vukovar}

At the beginning of 1991, Vukovar was a major river port on the Danube and home to more than 40,000 people of mixed ethnic backgrounds; $47 \%$ were Croatians, 32.3\% Serbs, and $20.5 \%$ of other backgrounds [8]. The Vukovar Municipal Assembly, which had a Serbian majority (including a number of Serbs who presented as "Yugoslav nationality"), refused 
to endorse the Constitution of the Republic of Croatia and acknowledge Croatian independence and sovereignty. Instead, local Serbian paramilitary formations were organized and soon were enforced by paramilitary formations from Serbia, as well as by the YPA. The artillery, air, and infantry attacks lasted until the YPA army and Serbian paramilitary forces entered Vukovar on November 18, 1991, after a siege lasting nearly three months [4].

Representatives of the Republic of Croatia, the YPA, the International Red Cross, Doctors Without Borders/Médecins Sans Frontières (MFS), and the Maltese Cross struck the "Agreement to Neutralise the Vukovar Hospital and Organise Convoys to Evacuate the Wounded and Ill from the Hospital", which urged both warring parties to recognize the neutrality of the hospital and to cease fire along the evacuation route for the 40 severely ill and 360 wounded, under the supervision of the European Union Monitoring Mission (EUMM) [9]. Despite the agreement and fruitless efforts of international organizations to reach the hospital, on the morning of 20 November, approximately 300 wounded and civilians were forcibly escorted from the hospital in military buses by members of the YPA [10].

\section{Ovčara}

After the YPA and Serb paramilitaries entered Vukovar Hospital on 20 November 1991, some patients were released, some taken to prisoner of War camps in Serbia, and around 250 disappeared. Of those, 200 killed in 1991 were exhumed from the Ovčara mass grave in 1996, some were discovered in other graves, several returned from prisoners' camps, seven survived the execution at Ovčara, and the others are still missing i.e., their bodies have not been recovered to date, although there are witness testimonies to their execution [11].

\section{Investigation of the Ovčara war crime by the International organizations}

The aim of forensic analysis is to prove the guilt or innocence of the accused [12, 13]. The primary task of forensics in the international investigations of war crimes, crimes against humanity, and genocide, is to locate and uncover mass graves, identify bodies, and collect material evidence and physical traces of human and natural processes which may prove necessary for the prosecution and punishment of the perpetrators [14]. International organizations, such as the UN, have collaborated with NGOs in launching investigations into serious human rights violations worldwide [15]. In the same vein, international forensic teams have investigated mass grave sites in the former Yugoslavia to unravel the truth about the crimes committed and identify their perpetrators and victims. The work of Physicians for Human Rights (PHR) and the International Commission on Missing Persons (ICMP) has been especially important [16].

Taken aback by the sheer number and severity of crimes committed in the former Yugoslavia, PHR and ICMP founded a Zagreb office in April 1996, independent of the ICTY, to coordinate their work as efficiently as possible. By establishing an ante-mortem database of missing persons, they set in motion the process of identifying the remains. Their operations proceeded in five stages $[17,18]$ : 
1. a team of forensic archaeologists and anthropologists identified the general location and potential site of the mass grave and estimated its size;

2. the forensic archaeologists and anthropologists performed exhumation and osteological examination of exhumed remains and estimated the minimum number of individuals in the grave;

3. forensic pathologists autopsied the exhumed remains to determine the cause and manner of death and basic biological data such as age, sex, stature, etc.;

4. ante-mortem data on missing persons was gathered to create databases;

5. forensic reports, autopsy findings, photographic, audio, and video recordings, and other evidence collected at the scene were compiled for submission to the International Criminal Court for further processing.

As part of the PHR team, forensic experts took an active part in locating and exhuming the Ovčara mass grave and then presented and interpreted the collected evidence in judicial proceedings [19]. The epilogue of the investigation revealed that the remains from the mass grave clearly belonged to civilians, the wounded, prisoners of war and medical personnel who had gone missing from Vukovar Hospital on 20 November 1991.

On the initiative of then-US President Bill Clinton, the ICMP, alongside the PHR, played an invaluable role in identifying more than 40,000 people who were reported missing from the area of former Yugoslavia during the war. Although the fate of many missing persons remains unknown, the organization had remarkable success and identified more than $70 \%$ of those reported missing [20]. In the course of its work, it developed a unique specialized database (Federal Document Management System (FDMS)) of missing persons worldwide, thus refining the classical methods of identification from DNA analysis [21].

The current analysis and report has several objectives:

1. to assess the contribution of the forensic analysis to the scientific-based forensic examinations and documentation;

2. to place the crime into historical context;

3. to determine whether the victims from the Ovčara mass grave were executed, and

4. to recognize the participation of YPA commanders in the planning of the Ovčara crime.

\section{Data sources for the review}

This review paper is largely focused on the analysis of documents created by the international forensic team and participants in the exhumation and forensic investigation on the Ovčara mass grave conducted for the purposes of the International Criminal Court, transcripts of testimonies of forensic experts in the following cases: Dokmanović, Karadžić, Milošević, Mrkšić et al., and Šešelj, retrieved as publicly available archival court documents from the ICTY database, as well as reports of the Special Rapporteur of the UN Commission on Human Rights from the UN Digital Library [1, 22, 23, 24, 25, 26].

The outlined forensic aspects of the investigation and identified evidence on the manner 
and cause of death are drawn from the final report by a certified forensic medicine specialist, Professor Y. I. Milewski, as well as 200 individual autopsy reports on bodies exhumed from the Ovčara mass grave. The analysis of exhumed bodies by identification method presented in this paper is grounded in the data from the forensic report written by Prof. D. Strinović, PhD, a forensic medicine specialist and representative of the Commission on Detainees and Missing Persons [24, 25, 27].

Forensic documentation was used as relevant evidence in the aforementioned court cases against the accused of Ovčara crimes before the International Criminal Tribunal for the former Yugoslavia (ICTY) [28].

In addition to the databases, other references were also consulted in the making of this paper, such as books, publications, newspaper articles, and articles from scientific journals, as cited in the references.

\section{Forensic aspects of the investigation of the Ovčara mass grave}

In October of 1992, in the wake of the mounting evidence of war crimes and mass graves in occupied Croatia, including the disappearance of more than 300 people from Vukovar Hospital, Clyde Snow, PhD, President of the PHR and Special Rapporteur of the UN Commission on Human Rights, met a surviving witness of the alleged execution at the Ovčara farmland near Vukovar [22, 29].

\section{The key witness}

The witness, a member of the Croatian National Guard, having suffered minor injuries, had, like many Vukovar locals, sought shelter at Vukovar Hospital, where he awaited the arrival of the International Red Cross and the promised evacuation to the free territory of the Republic of Croatia. He recounted the events that, instead of freedom, brought torture and death for many [29]. On the morning of 20 November 1991, while deliberately blocking the entry of international organizations into the hospital, YPA soldiers under the command of Major Veselin Šljivančanin singled out men, including the wounded, civilians, and hospital staff, as well as two women and three boys, and transferred them, in military buses and under armed military escort, to the barracks at Sajmište and then to a remote farm at Ovčara, where the planned mass execution took place [30].

The abuse started immediately upon disembarking at Ovčara. On the way to the barns, they were met by YPA who handed them over to members of Serbian paramilitary formations who, before the execution, beat them with wooden sticks, poles, chains, crutches, and gunstocks. According to the testimonies of surviving witnesses, the hours-long beating and psychological abuse continued in the hangars. At least two men were reportedly beaten to death and several were taken outside and disappeared without a trace [30, 31]. Surviving witness Z. Novak testified about the removal of the prisoners. Under the cover of night, a military truck carrying a small group of prisoners of war, including the witness, headed in the direction of Grabovo and after about one kilometre turned left, onto a dirt road banked by a wooded grove and swamp on the right and by cultivated fields on the left 


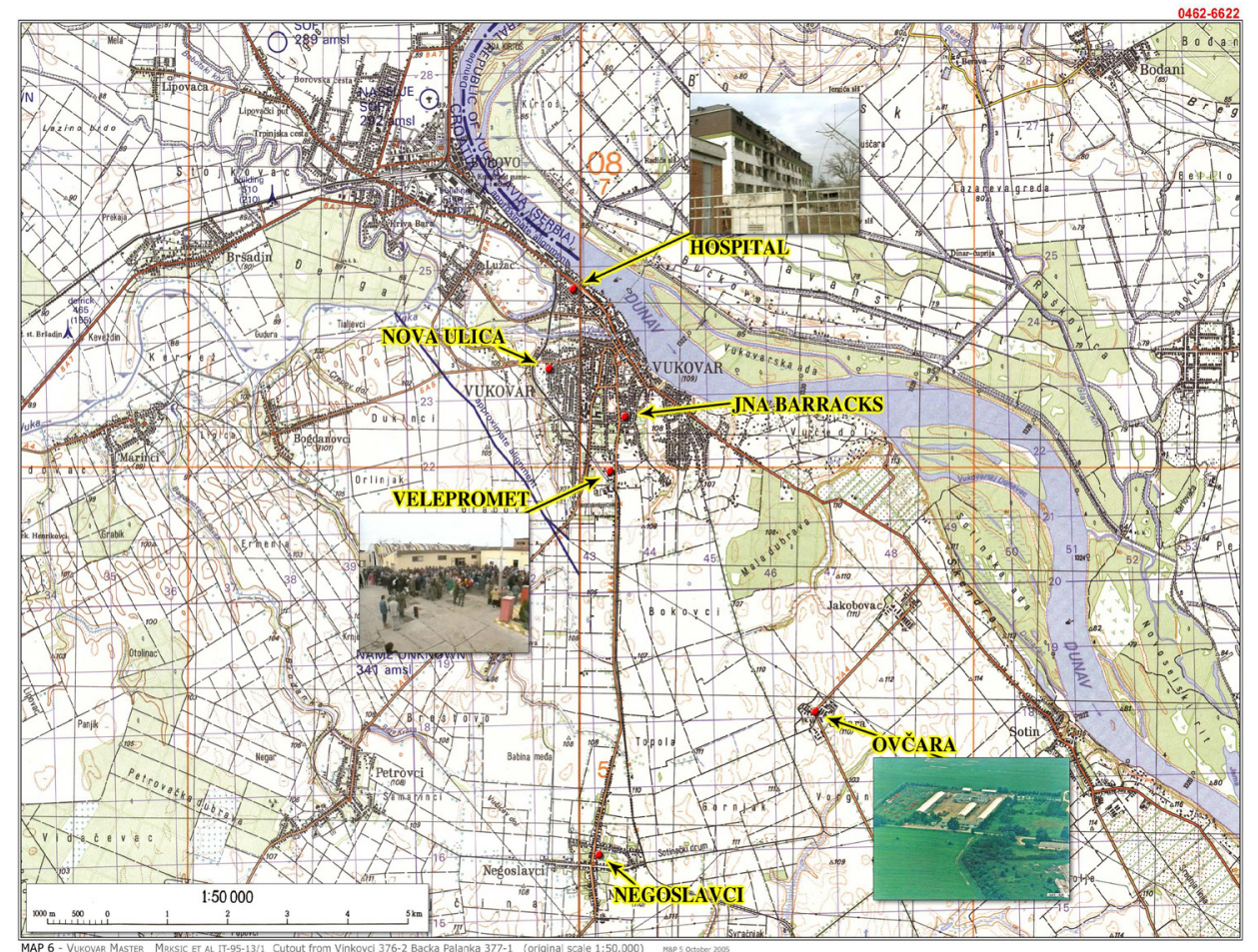

Figure 1. Topographic map of the road leading from Vukovar Hospital to the Ovčara mass grave [30] (reproduced with permission).

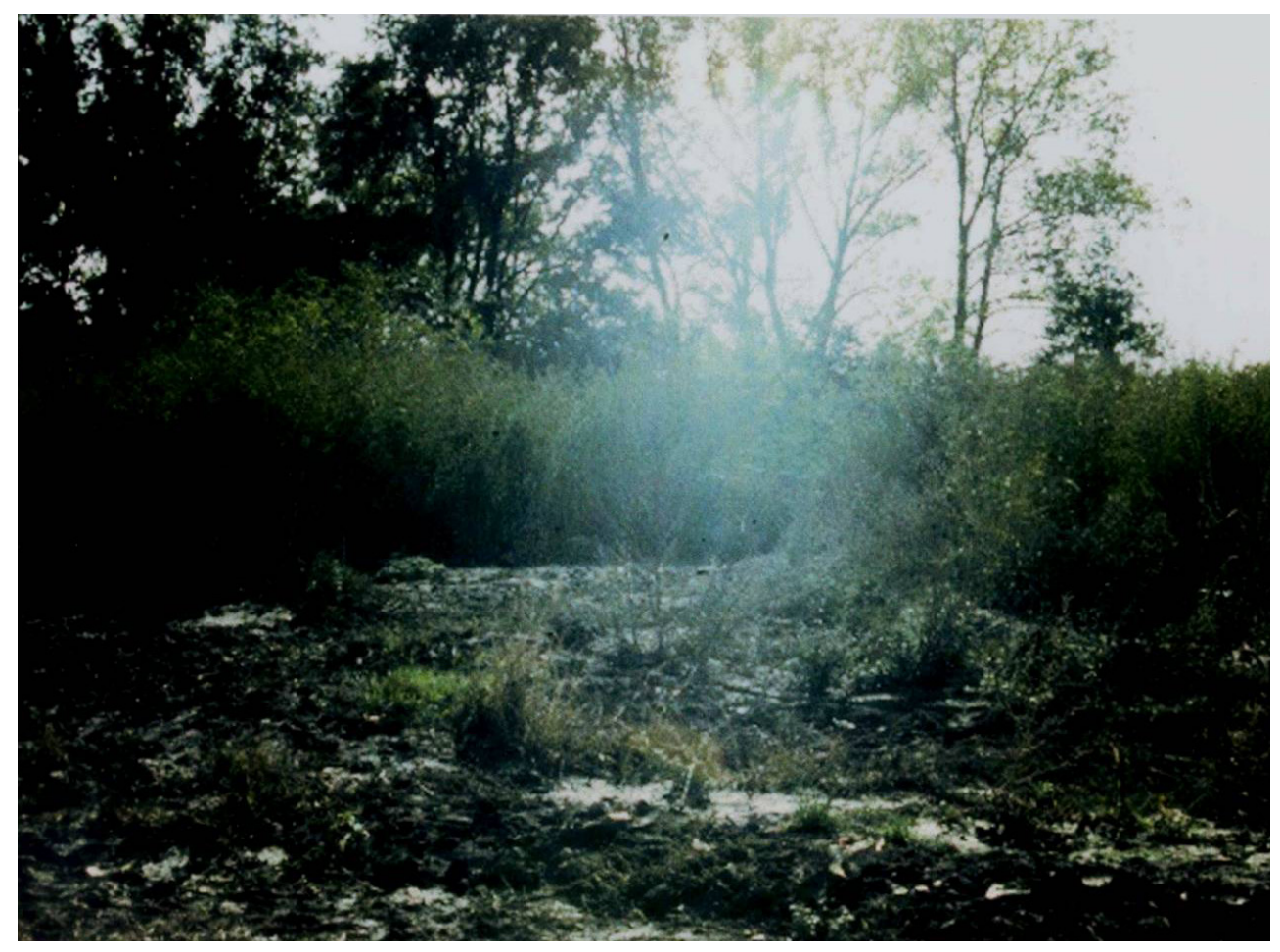

Figure 2. The location of the grave at the Ovčara farmland near Vukovar [24] (reproduced with permission). 
[29, 30]. There was an armed soldier in the front of the vehicle, but no one followed behind them, so the witness decided to flee; he lifted the tarpaulin, jumped out of the truck, and started running towards Vukovar [28, 30].

The information he gathered and a topographic map containing the location of the alleged crime scene was sufficient evidence for Dr Snow to inform Commission members of his findings and request permission to investigate the area [22, 32] (Figure 1).

Upon his return to Erdut, on 18 October 1992, Dr Snow and his entourage launched an investigation into the alleged mass grave site [22] (Figure 2).

Using a topographic map containing

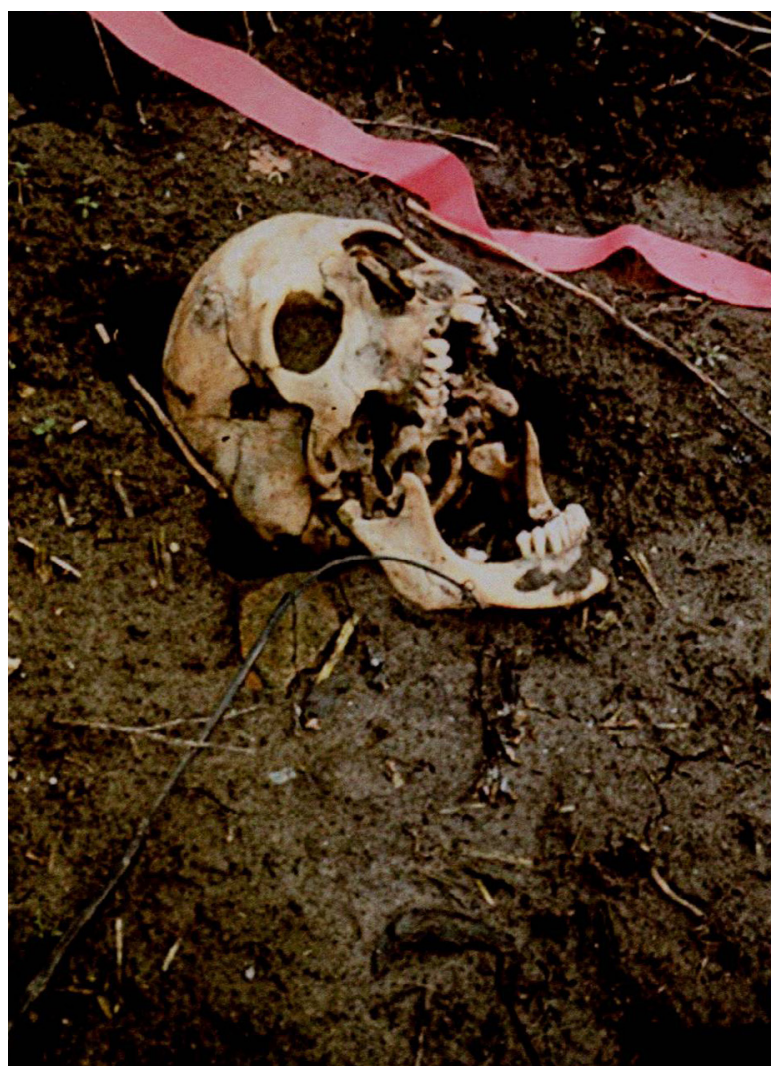

Figure 3. A photograph of the skull on the surface of the Ovčara mass grave [24] ( reproduced with permission). the witness-reported location of the detention site and the approximate place where he jumped out of the truck, Dr Snow's team made a stop near the Ovčara farm [22, 33]. At the top of a ravine, about $900 \mathrm{~m}$ away from the main road, they noticed an anomaly in soil and vegetation. Dr Snow concluded that this was a product of human activity no older than a year [22]. Shallowly buried human skeletal remains had risen to the soil surface - a skull with an open jaw and a visible bullet wound on the left side. A short distance away, at the edge of the forest, they found a partially skeletonized body with sun-bleached bones and very little clothing [22] (Figure $3)$.

The exposed skeletal remains were severely damaged due to animal activity and other external factors, but they were assumed to have belonged to young men [22].

The Special Rapporteur of the UN Human Rights Commission subsequently published the discovery of the exact location of the Ovčara mass grave in his report in late October 1992, but it would take almost four years for the start of the exhumation [32]. Although controlled by the so-called government of the Republic of Serbian Krajina during this period, the gravesite was under the constant protection of UN forces [1].

\section{Preliminary investigation of the gravesite}

Shortly after the existence of the gravesite at Ovčara was confirmed, the Special Envoy of the UN Secretary-General recommended to the Special Rapporteur of the Commission on Human Rights to carry out the investigation as soon as possible to protect key evidence [32]. Although the local authorities did not consent to the investigation, in December 1992, 
under the auspices of the UN Commission of Experts, a four-member forensic team deployed by the PHR conducted a preliminary investigation [34]. The investigation began with a security check; simultaneously, aerial footage was taken of the gravesite in its natural environment and the overgrown surface vegetation was then cleared [34] (Figure 4).

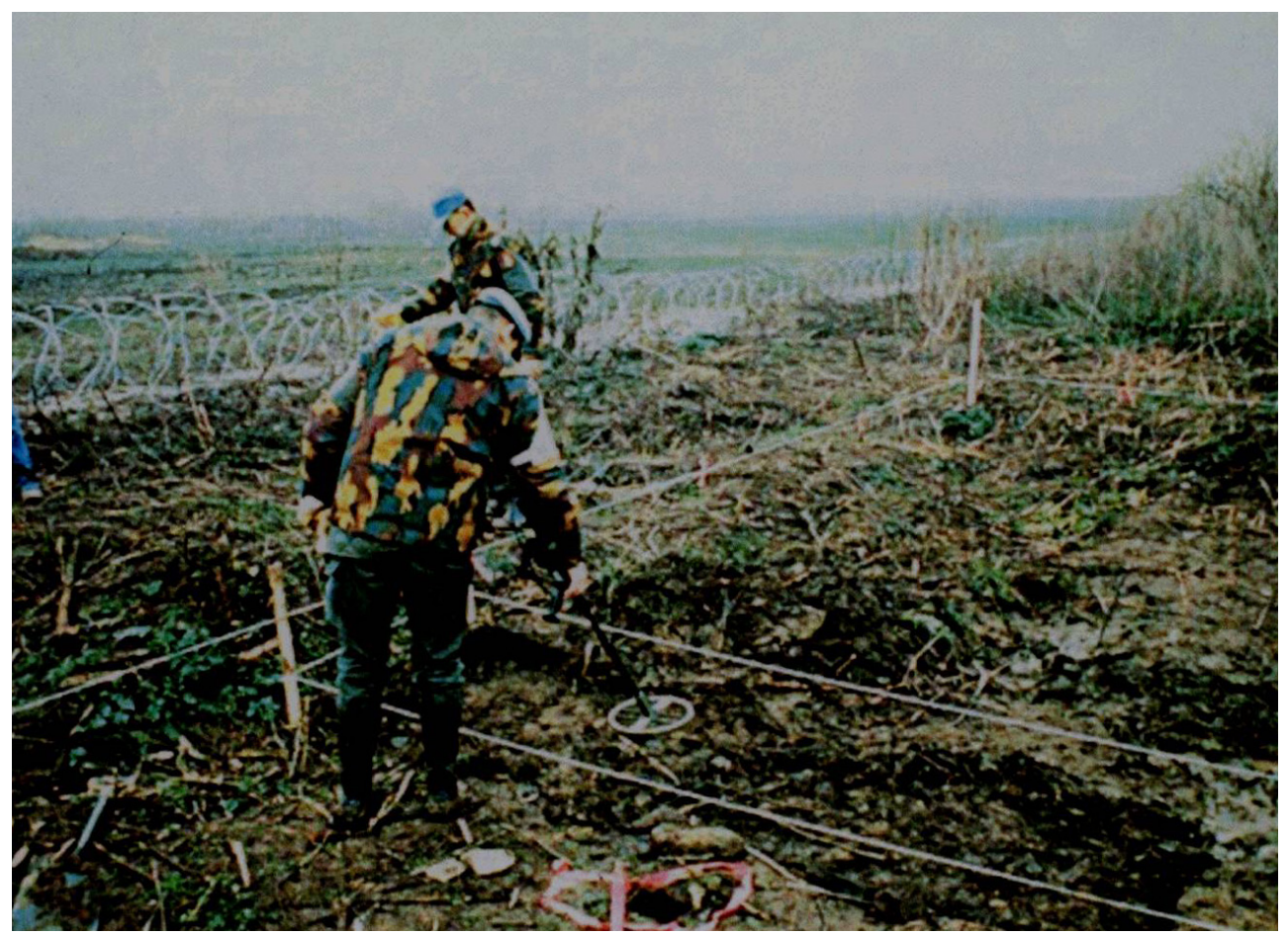

Figure 4. A topsoil security check with a metal detector at, at that time, alleged mass grave site at Ovčara [24] (reproduced with permission).

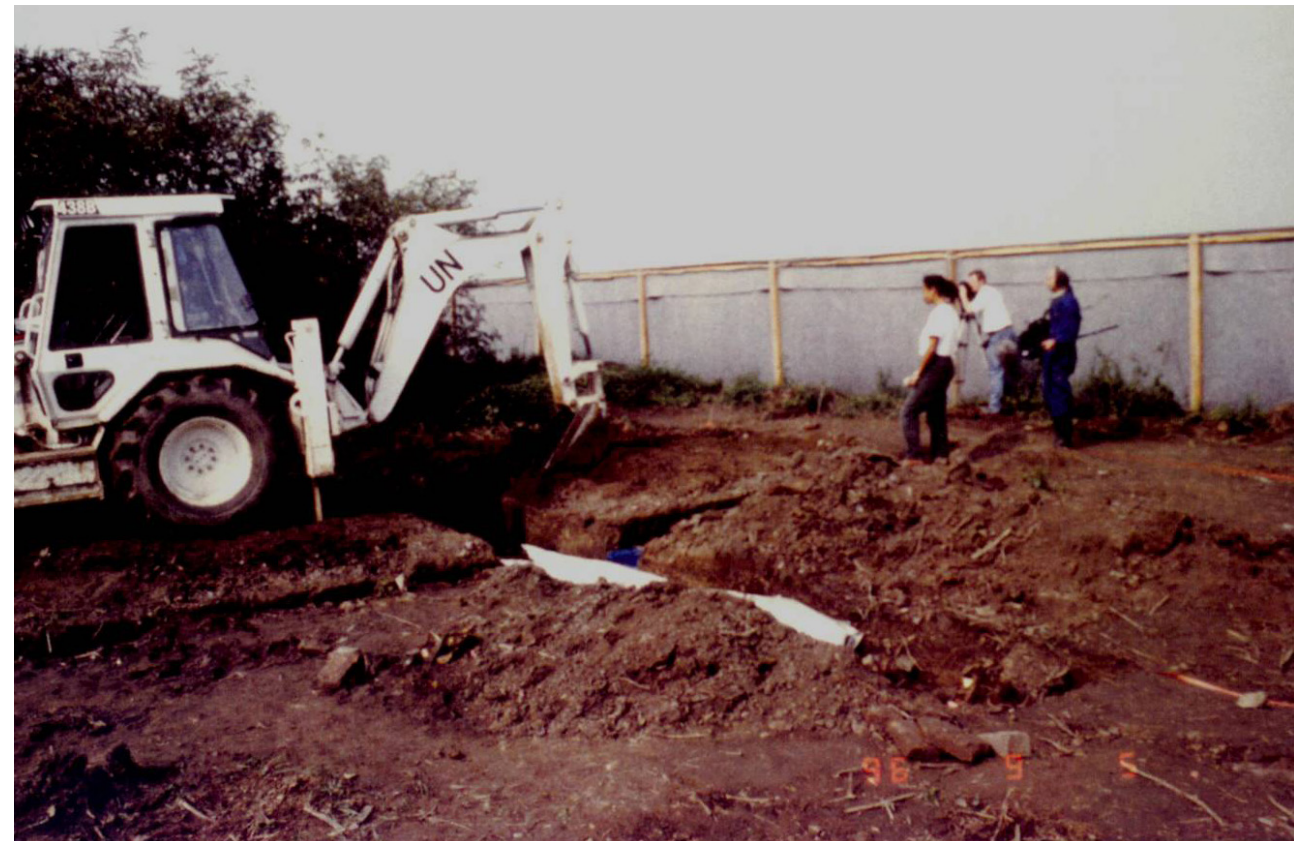

Figure 5. The excavation of the test trench across the surface of the mass grave at Ovčara [24] (reproduced with permission). 
The water that had accumulated was removed by digging a drainage ditch and the surface was then cleared of remains of dead animals and various waste [22, 30]. Visible traces of heavy machinery at the centre of the gravesite suggested that the $7 \times 9 \mathrm{~m}$ grave was dug deliberately. To measure the size of the original grave and its content, a test trench was dug across the, at that time, alleged mass grave site, $1 \times 7 \mathrm{~m}$ in length and $80 \mathrm{~cm}$ deep. This revealed nine bodies, buried partly or entirely in the excavated trench, lying intertwined and in disarray. This fully confirmed the testimony of the witness about the crime that had been committed at Ovčara [22] (Figure 5).

Necklaces with Catholic crosses and a medallion with the inscription "Bog i Hrvati" (God and the Croatians), such as were often worn by members of the Croatian Armed Forces, were discovered on the partially skeletonized bodies of young men that were found outside the grave [34] (Figure 6).

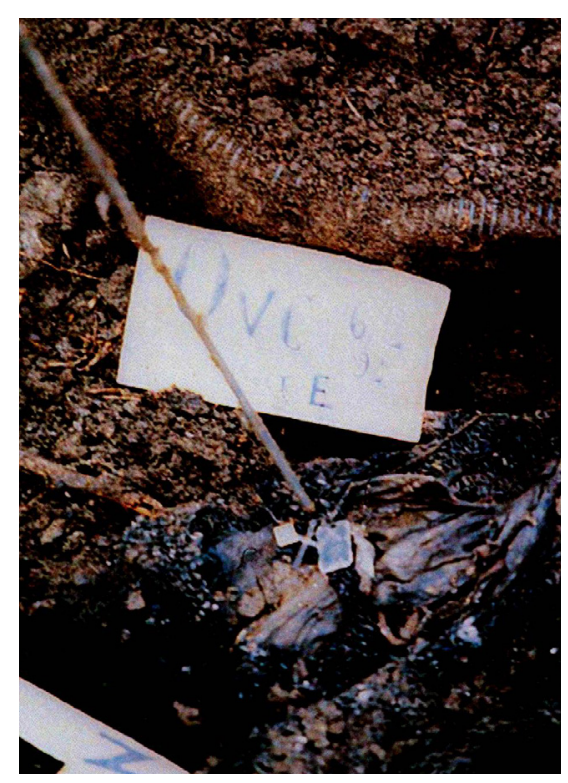

Figure 6. A necklace with Catholic insignia found on a body outside the Ovčara grave [24] (reproduced with permission).

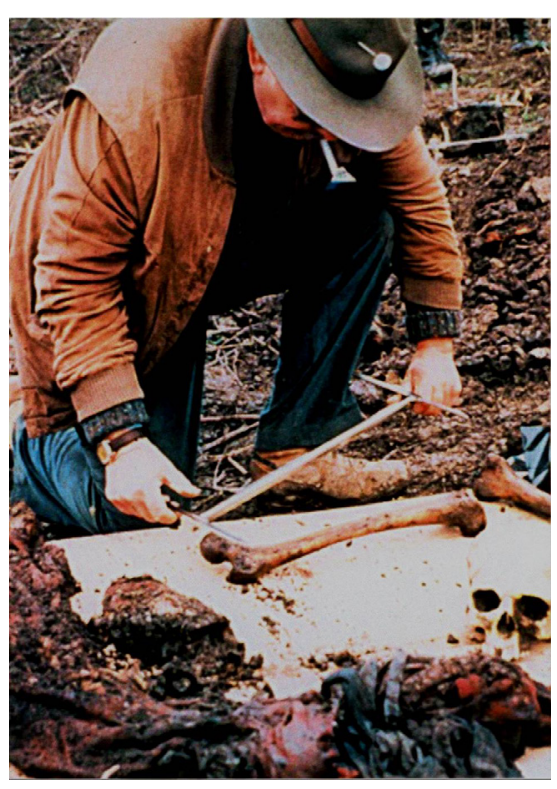

Figure 7. Dr Snow examines skeletal remains discovered outside the grave [24] (reproduced with permission).

The first remains were discovered at a depth of $22 \mathrm{~cm}$ and the others at an initial depth of $60 \mathrm{~cm}$ [22, 35]. Since the bodies had to be preserved in their original condition, only a visual anthropological examination of the available findings from the test trench was performed. Gunshot head injuries were identified in at least two bodies [22] (Figure 7).

Based on the distance of the second body, which was found at the edge of the forest, Dr Snow hypothesised that the deceased had either been killed while fleeing or executed after the grave was already filled, or that he had managed to escape from the grave and then died shortly afterwards from severe injuries [22].

The skeletal remains found outside the grave were examined, placed in plastic bags labelled "OVC-01" and "OVC-02", and laid at the end of the test trench, and all the bodies were then covered with black foil and reburied for preservation [22, 34] (Figure 8). 
A detailed examination of the gravesite surroundings to the west and northwest revealed a large number of $7.62 \times 39 \mathrm{~mm}$ shell casings characteristic of the AK47 that was used by the YPA at the time [22] (Figure 9).

The location of the spent shell casings led forensic investigators to conclude that the shots were fired diagonally across the gravesite, i.e., that the perpetrators stood alongside the north side of the grave, about $4 \mathrm{~m}$ from the dirt road, and the prisoners on the south or southeast side. The conclusion that the site was both the place of interment and execution was corroborated by bullet scars that littered the surrounding trees [34].

The preliminary investigation produced detailed documentation on the findings from the exhumation

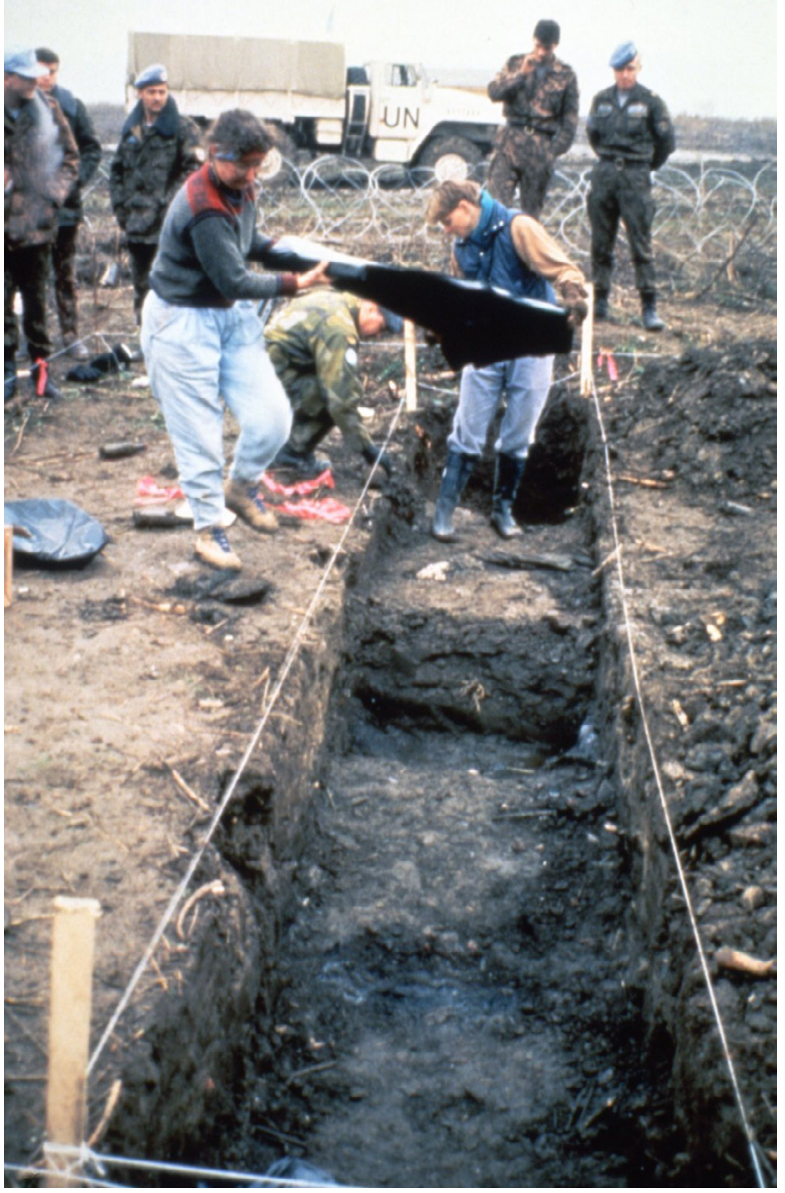

Figure 8. The preservation of bodies from the test trench during the preliminary investigation of the Ovčara mass grave [36] (reproduced with permission). site, exhumation methods, and examinations of the bodies, which was supplemented by hand-drawn sketches as well as photo and video recordings [37] (Figure 10). Following the preliminary investigation, the team's priority was to secure the crime scene; the site was cordoned off with two rows of concertina wire and UNPROFOR Russian Battalion (RUSBAT) guard stations were placed

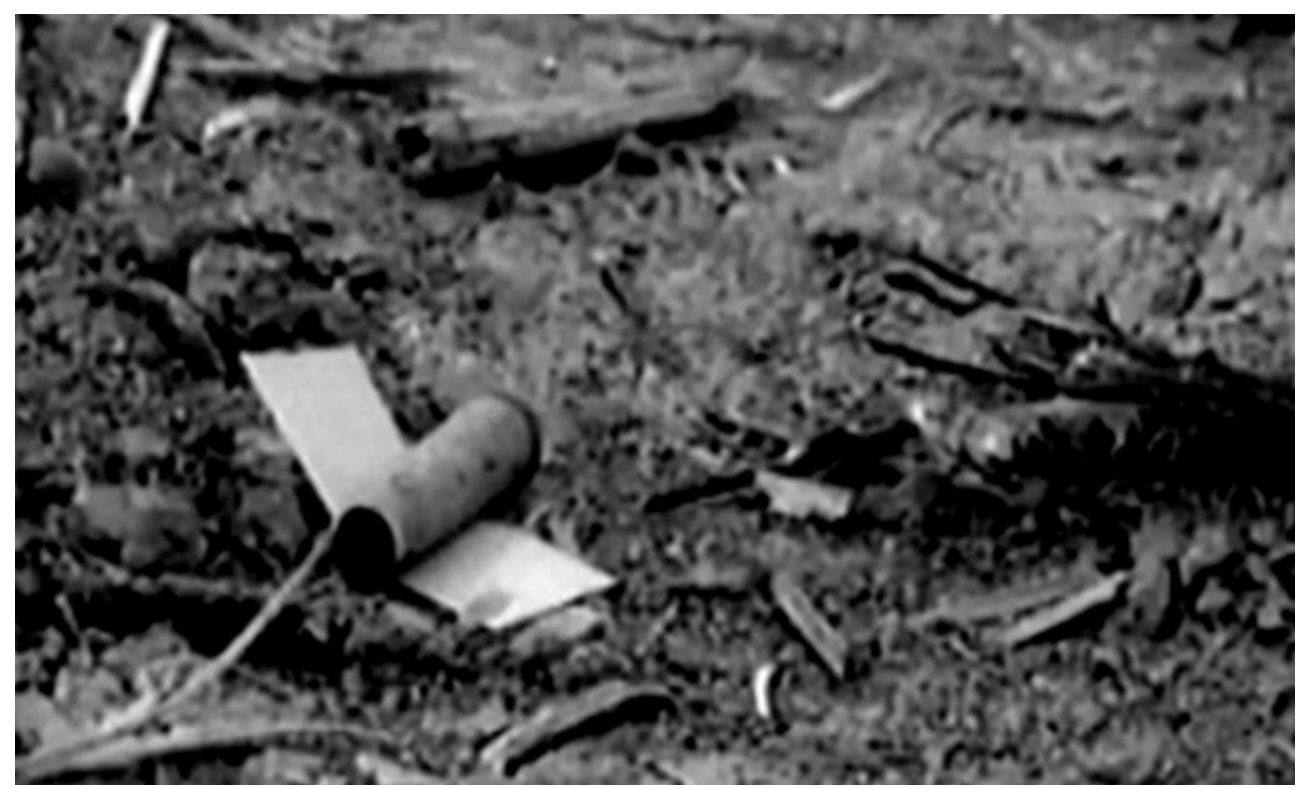

Figure 9. Spent AK47 ammunition on the surface of the Ovčara mass grave site near Vukovar [36] (reproduced with permission). 


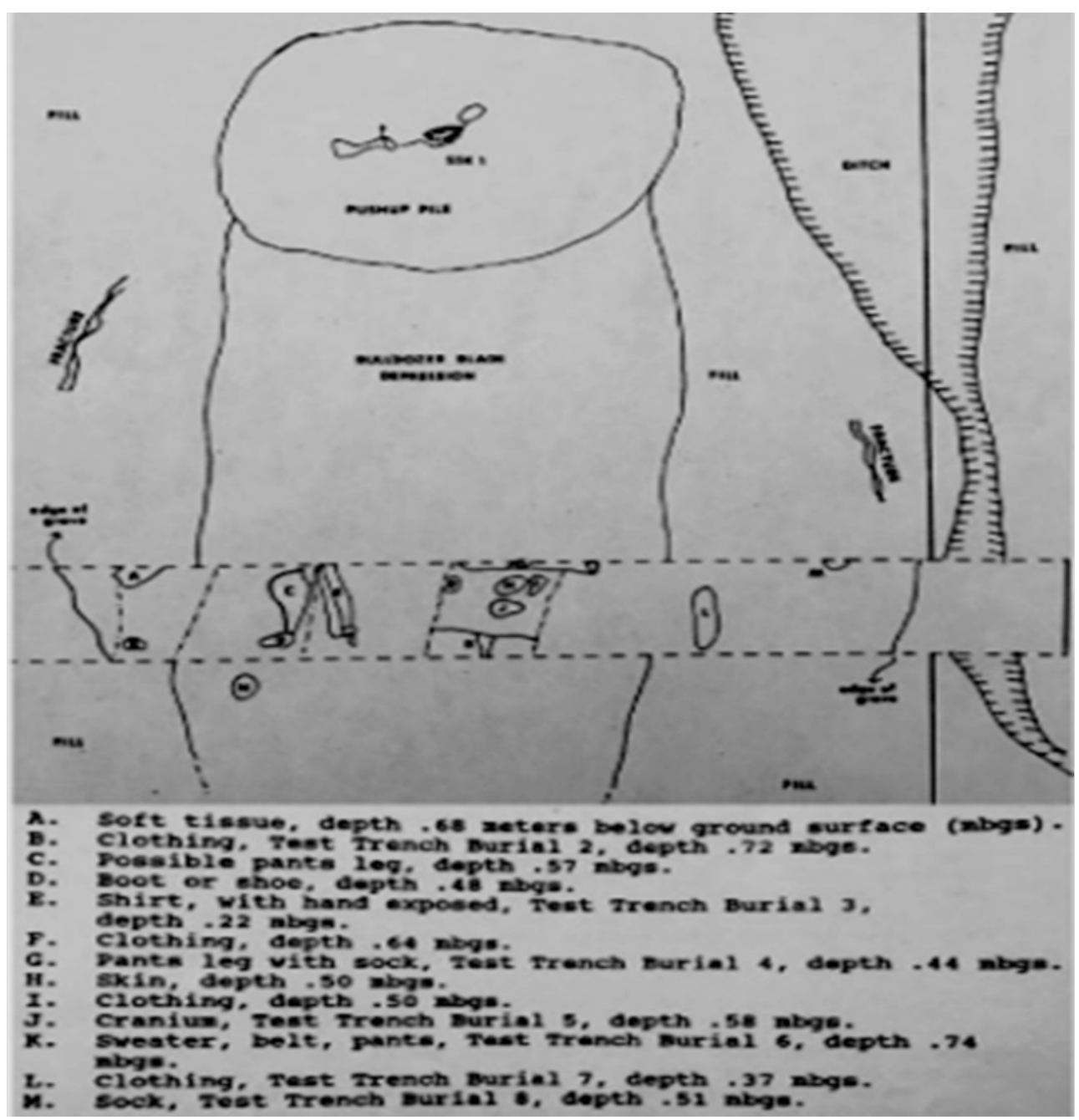

Figure 10. A sketch by Dr Snow drawn during the first survey of the Ovčara mass grave site in December 1992 [36] (reproduced with permission).

alongside the dirt road and surrounding fields; the control was transferred to the Jordanian Battalion (JORBAT) before the exhumation [29, 38].

After analysing the findings from the preliminary investigation, the forensic team considered that the site contained a mass grave with more than 200 bodies of victims of mass executions, most likely Croatian nationals, with no visible signs of contamination, and that almost all evidence matched the witness statement [34].

To carry out the final exhumation, led by Dr Snow, a team of eighteen forensic experts, funded by the UN Commission, returned to Ovčara in October 1993. However, the agreement with the Serbian military and civilian authorities, which had been signed in Knin and authorised the exhumation, was disputed. Under threat of force, the forensic team left the examination site 48 hours later. Additionally, 64 items of evidentiary significance, mostly shell casings found at the site, were seized. During their short stay at the site, the team found that the gravesite was overgrown with dense vegetation. Access was cleared and electronic mapping was carried out to measure the size of the grave [22, 34]. This development revealed that, although the UN Commission provided the necessary staff and equipment, the UN Protection Force did not possess sufficient military resources to support the investigation. It was also concluded that the local authorities had the power to challenge decisions made on higher instances [34, 37]. 


\section{Exhumation}

After signing the agreement on the peaceful reintegration of the Croatian Danube region and bringing charges before the ICTY against the so-called "Vukovar Three", as YPA Officer Miroslav Radić, General Mile Mrkšić, and Major Veselin Šljivančanin had become known, the exhumation of the mass grave at Ovčara became a pressing need as a way to obtain relevant material evidence against the accused [36].

Consequently, the ICTY Prosecutor's Office ordered the exhumation of the mass grave to achieve four objectives [23]:

1. find the evidence required to identify the victims;

2. determine the cause and manner of their deaths;

3. connect the primary and secondary gravesites;

4. expose attempts to conceal the crime.

Implementing the ICTY order to survey and clear the gravesite of explosives, the UN Administrator of Vukovar assembled a command team to clear the area of mines, and the whole site was thus made safe [39]. With the aid of topographic maps made during the preliminary investigation in 1992, the forensic team successfully located the gravesite and began the exhumation [36]. The exhumation was carried out from 31 August to 4 October 1996, under the direction of ICTY investigators. Based on the indictment against Mrkšić et al. [31], the operative part of the exhumation was carried out by a five-member PHR team led by Dr W. Haglund, in the presence of representatives of the Croatian and Yugoslav authorities [36]. Besides the PHR, several other international organizations took part in the exhumation, including the ECMM, ICMP, and the Organization for Security and Cooperation in Europe (OSCE) [1].

The gravesite survey started by measuring the size and examining the topsoil for any surface evidence [24].

The exhumation began by removing the topsoil mechanically. The black film that was utilized by the first team of forensic experts to protect the skeletal remains from the test trench upon completion of the preliminary investigation in 1992 was uncovered on the third day [36]. The exhumation carried on by manual digging and other archaeological methods to preserve the bodies and evidence [39] (Figure 11).

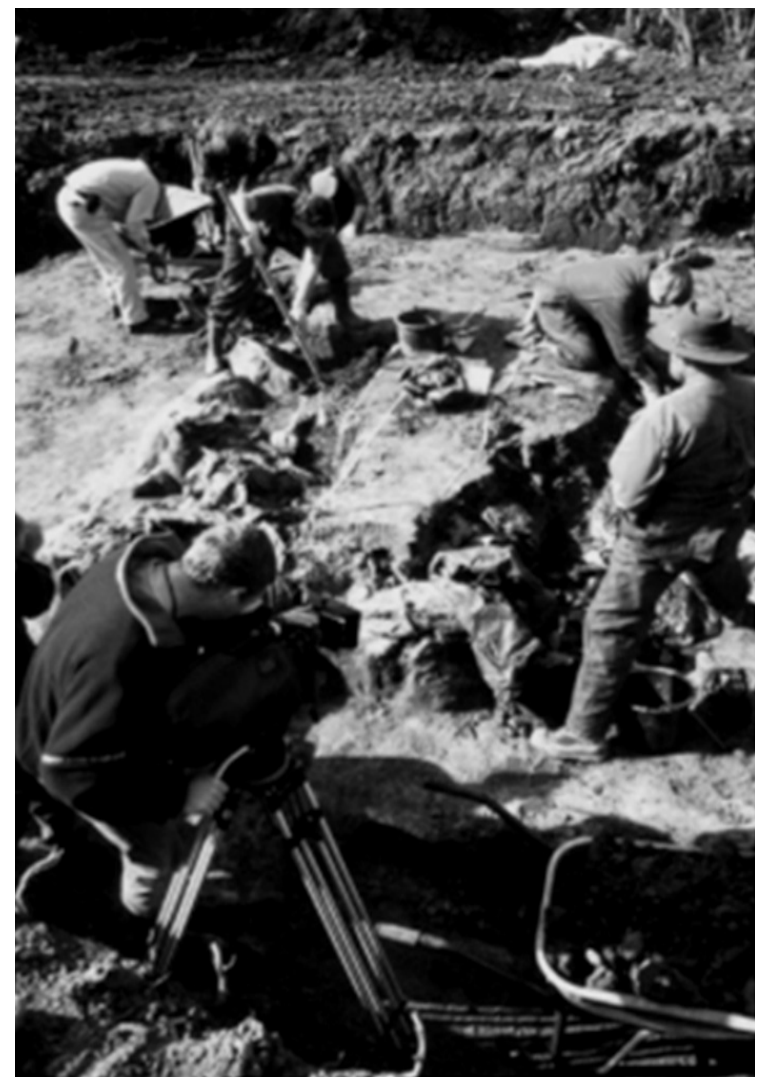

Figure 11. The PHR team manually removes earth from the Ovčara grave [36] (reproduced with permission). 
The team unearthed scores of entwined bodies piled up in a pyramidal heap, including bodies of hospital staff dressed in work wear and shoes as well as bodies dressed in hospital wear and equipped with medical devices, such as catheters, bandages, plaster, crutches, etc. [39] (Figure 12).

The bodies were entangled due to several factors, such as natural processes, direct animal or human activity, or excavation machines and tools, which slowed down the exhumation process and made it difficult to estimate the minimum number of individuals in the grave [1, 39] (Figure 13).

Each body was electronically mapped, placed in white plastic bags together with any associated evidence, and labelled according to the order of excavation, from "OVC-001" to "OVC-200"

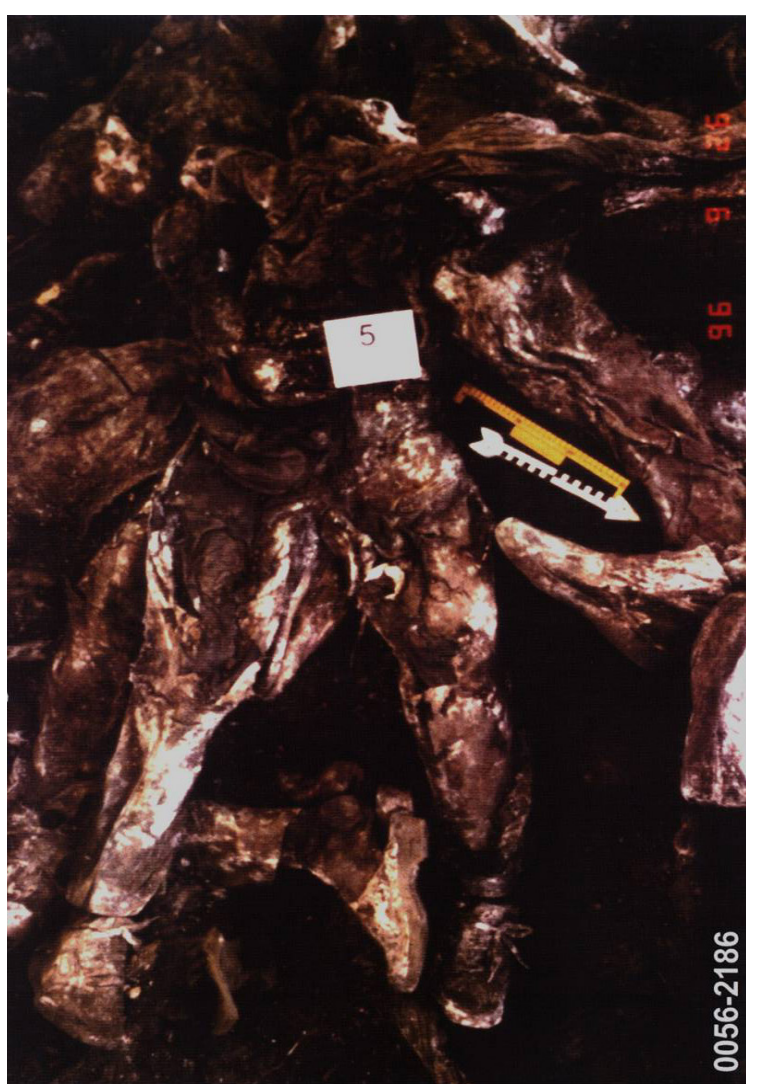

Figure 12. Entwined bodies dressed in civilian clothes and work wear and shoes [24] (reproduced with permission).

\section{[25].}

The first lot of exhumed remains was transported to the Institute of Forensic Medicine in Zagreb for further processing. The last of the 200 victims was exhumed on 4 October 1996 [36].

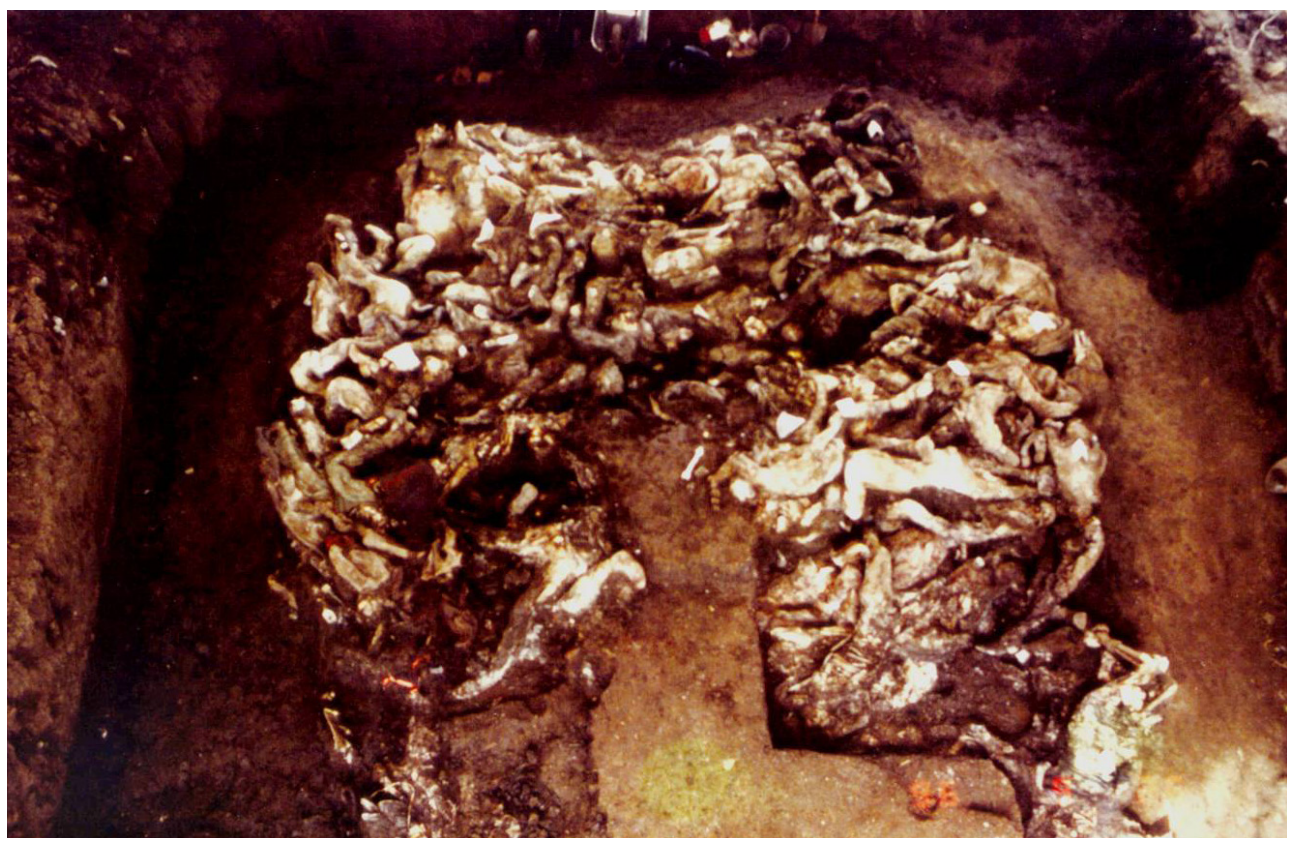

Figure 13. Entangled bodies in the Ovčara mass grave [24] (reproduced with permission). 


\section{The autopsy report on the bodies exhumed from the Ovčara mass grave}

From 5 October to 16 November 1996, an international forensic team consisting of eleven forensic medicine specialists and supporting staff working at the laboratory of the Institute of Forensic Medicine under the Zagreb University School of Medicine, performed the autopsy of the 200 bodies exhumed from the Ovčara mass grave to determine the cause and manner of death as well as other information required for identification purposes by the Commission on Detainees and Missing Persons, which oversaw the exhumation [1, 27]. The work of forensic experts was supervised by the Deputy Director of the Croatian Institute of Forensic Medicine and member of the Croatian Government Commission on Missing Persons and Detainees, Professor Davor Strinović (Zagreb University School of Medicine, Zagreb, Croatia), in the presence of forensic experts, who were there on behalf of Yugoslavia [24]. A thorough forensic examination of the remains was performed by an international forensic specialist who then, based on the collected data, personally compiled a report containing meticulously documented findings from the post-mortem examination and an opinion on the cause and manner of death. By its decision, ICTY authorised the certified forensic specialist and assistant professor of clinical medicine at the New York University Medical School, Y. I. Milewski, to write up the final report of pathological findings at autopsy [25, 27].

The final report by forensic specialist Y. I. Milewski, entitled "Analysis of Pathologic Findings at Autopsy of the Individuals Exhumed from the Ovčara Grave near Vukovar, Croatia”, lists three important components observed during autopsy: data relevant for identification, the procedure, and final results of external and internal examinations of bodies, and determining the cause and manner of death [27].

\section{Data relevant for identification}

Data that were recognised as potentially relevant for identification at autopsy included sex, age, height, hand dominance, ante-mortem trauma, special features, clothing, and personal effects [22].

The first phase of the examination started with X-ray scans to detect the presence of metal objects in the bodies and clothing, followed by the inspection of clothing from the bodies for any sign of tear that could point to a certain type of injury. The final stage of autopsy consisted of an external examination of the skin, skeletal structure, and preserved organs in a minority of exhumed bodies [27].

\section{Examination of garments}

Layered clothing was instrumental in the preservation of most exhumed bodies, except for the few who were without any clothing or personal effects. To preserve fragmented skeletal remains and ballistic evidence, the bodies were placed in labelled bags during the removal of the clothing. After cleaning and drying, the clothing was inspected, every piece was photographed and described, the design, pattern, type, colour, features, labels, name of manufacturer and size were analysed, and the garment was then labelled with the same label as the body [1]. The information on clothing and any personal effects found inside or next to the clothes was recorded in the forensic medical specialist reports. While referring 
to clothing as a crucial piece of evidence showing the victims were injured, forensic medicine specialist Dr Y. I. Milewski remarked that 34\% of the exhumed bodies wore hospital clothing [27].

\section{External and internal body examinations}

The external examination of the bodies yielded ante-mortem data on medical treatment. Particular emphasis was placed on describing special bodily features, such as scars, tattoos, moles, fractures, aesthetic procedures, firearm or blunt force trauma, or a combination thereof [1, 22] (Figure 14).

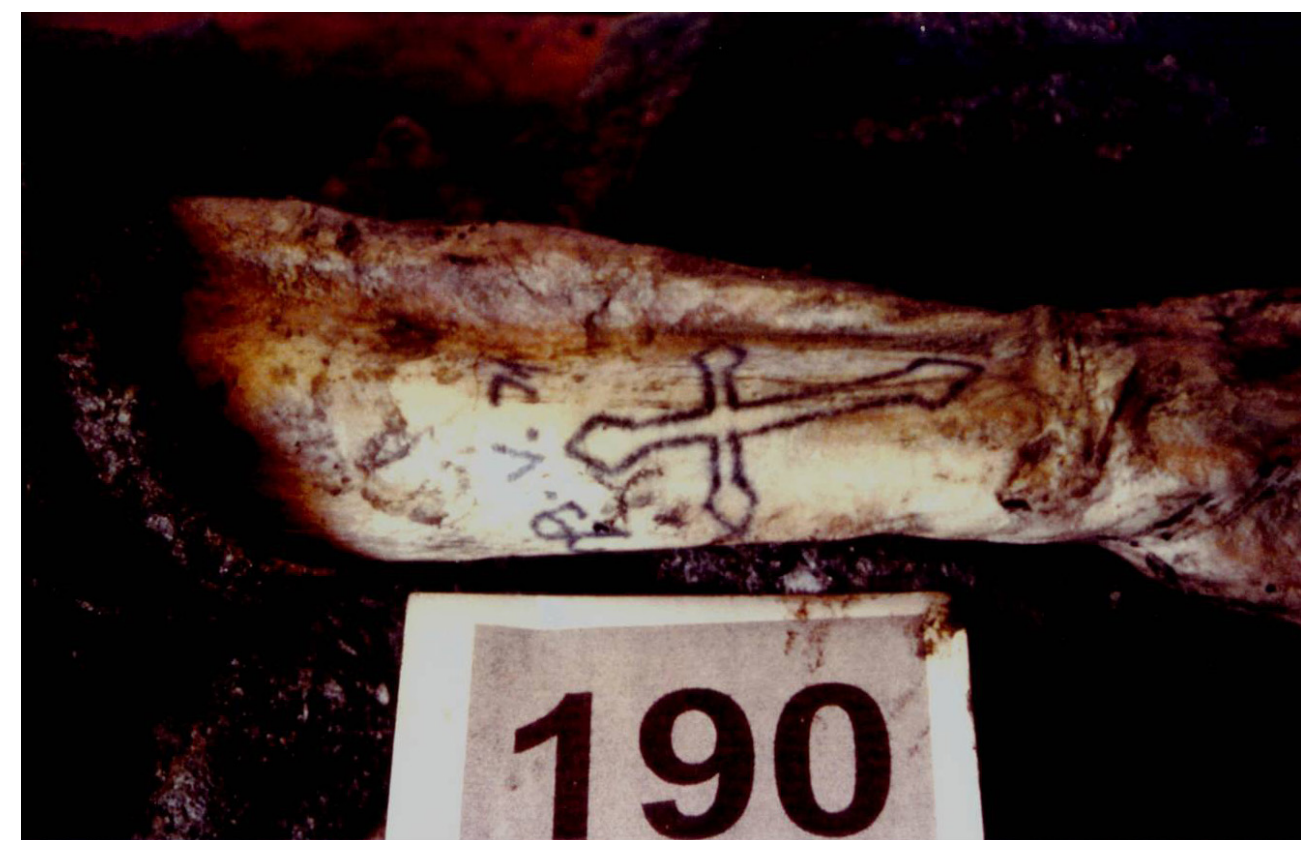

Figure 14. An external bodily feature relevant to the identification process - a tattoo on the exhumed body labelled "OVC-190" [24] (reproduced with permission).

Forensic anthropologists analysed remains to estimate the sex, age, height, hand dominance, and other biological characteristics of remains that had no external physical features. Anthropological methods were used to estimate ante-mortem height by measuring the length of the femur and tibia, which was then used to estimate height [14, 22]. At the same time, the osteological examination of the pelvis demonstrated that 198 bodies from the grave were male and two were female [1,27]. Findings on pathological conditions and medical interventions were collected and documented during both the anthropological processing as well as all other examination phases, and in some cases, the cause of death was also determined. The examination results were recorded in the official autopsy report [25, 27].

In addition to collecting tooth samples for DNA analysis, a forensic dentistry specialist also documented the dental status for comparison with available ante-mortem dental records [24, 27].

Forensic medical examiners found internal organs in varying stages of preservation in $34.5 \%$ of the bodies; internal organs were not found in $65.5 \%$. Due to this factor, they were 
unable to detect ante-mortem pathological conditions and trauma conducive to the identification or peri-mortem trauma (possible causes of death due to soft tissue injuries, such as cut neck veins or stab wounds to the heart, without bone injury, resulting in exsanguination) [1, 24, 27].

Various factors contributed to the putrefaction and advanced decay of the bodies, causing changes in the colour and preservation of the skin, scalp, subcutaneous tissues, muscles, and internal organs [27]. Unlike the bodies that were buried at greater depths - which were saponified, with more or less preserved clothing as well as skin and hair $-42 \%$ of the bodies buried closer to the surface of the grave were partially skeletonized, with signs of disarticulation [1, 24].

Regardless of these changes, all 200 exhumed bodies from the Ovčara mass grave were fit for further forensic processing [27].

\section{Cause and manner of death}

The analysis of traumas and affected body parts revealed the manner of death of $96.5 \%$ of the corpses who had died a violent death - homicide, while the cause of death remains undetermined in $3.5 \%$ of the cases. Although visible putrefactive changes were present in the majority of the bodies from the Ovčara mass grave, a forensic examination successfully determined the cause of their death [27] (Table 1). All 200 bodies were examined. All underwent predominantly putrefactive changes, with no visible signs of mummification or complete skeletonization. Numerous injuries were detected, but only objectively described traumas, appropriately recorded in photographs or video, were accepted as evidence [1]. However, due to errors made by forensic experts while documenting the type and the location of trauma, such as inadequate descriptions or lack of photo recordings, the cause of death was reported as unknown in a small number of cases [1].

Table 1. Causes of death, number and type of injuries of bodies from the Ovčara mass grave

\begin{tabular}{lc} 
Cause of death & Number (\%) \\
Firearm trauma & $190(95)$ \\
Head injury & $48(24)$ \\
Head and torso injury & $71(38)$ \\
Head, neck, and torso injury & $9(5)$ \\
Neck injury & $2(1)$ \\
Neck and torso injury & $8(4)$ \\
Torso injury & $48(25)$ \\
Limb injury & $4(2)$ \\
Sharp force trauma & $1(0.5)$ \\
Combined firearm and sharp force trauma & $1(0.5)$ \\
Trauma from fatal violence - combined firearm and sharp force injury to the extremities & $1(0.5)$ \\
Undetermined & $7(3.5)$ \\
\hline
\end{tabular}

The cause of death for $95 \%$ of the individuals exhumed from the Ovčara mass grave was multiple gunshot wounds [24]. On the body labelled "OVC-174", the skin and soft tissues were sufficiently preserved to show a stab wound on the left side of the chest as well as 
two stab wounds on the left side of the neck. Aside from visible fractures of the mandible and lower extremities that are characteristic of firearm trauma, the analysis established the cause of death as sharp force trauma [1].

The body labelled "OVC-154" sustained a stab wound to the torso and head and torso injuries from firearms, all of which were potentially fatal, and so were consequently listed as the cause of death. The cause of death of the body labelled "OVC-188" was fatal violence. In seven cases, the cause of death was undetermined due to insufficient credible evidence of ante-mortem trauma and a lack of objective description in autopsy reports [27]. The largest percentage of firearm injuries to vital organs, $67 \%$, was observed in the head area, $25.5 \%$ of which were exclusively head injuries. Torso injuries were confirmed in $26 \%$ of the bodies and fatal neck injuries were recorded in two corpses. Multiple limb injuries were determined as the ultimate cause of death in only four people, as the advanced stage of putrefaction and the skin, soft tissues, and organ decay prevented the detection at autopsy of possible gunshot wounds caused by soft tissue injury with no bone contact [27] (Table 2).

Table 2. The classification of causes of death by firearm injury type

\begin{tabular}{lc} 
Classification by type of firearm injury & Number (\%) \\
Head injury & $48(25)$ \\
Head and torso injury & $71(38)$ \\
Head, neck, and torso injury & $9(5)$ \\
Neck injury & $2(1)$ \\
Neck and torso injury & $8(4)$ \\
Torso injury & $48(25)$ \\
Limb injury & $4(2)$ \\
\hline
\end{tabular}

Saponification and advanced putrefaction precluded the accurate determination of the number of gunshot wounds on the surface of the skin, in soft tissues, and organs in most of the exhumed bodies, but trauma to the bones was evident [1, 27]. Dr Snow's memorable statement, "bones are our best and last witnesses; they never lie and never forgive", once again proved correct [22].

\section{Identification of the persons exhumed from the Ovčara mass grave}

For processing and identification, 200 bodies were transported to the Zagreb Institute of Forensic Medicine, where an international forensic team examined the remains using classical forensic methods [9, 24]. At the outset of the identification process, the bodies were under the temporary supervision of Dr Snow. In 1997, the supervision was transferred to the Commission on Detainees and Missing Persons [1, 9]. From 1992 to 1996, forensic anthropologist Dr Snow, in cooperation with the Croatian authorities, worked on gathering information and creating a database with ante-mortem data on missing persons from Vukovar Hospital [22]. The comparison of ante-mortem and post-mortem data allowed the preliminary identification of 57 exhumed bodies during the forensic procedure [25]. An aggravating circumstance in the identification of a large number of exhumed bodies was the lack of reliable ante-mortem data, as these were destroyed in the Homeland War [40]. 
In cases that precluded identification by classical methods, DNA analysis proved successful in identifying $49.5 \%$ of the bodies; however, eight corpses could not be identified even using the database of missing persons from the Homeland War, which contains approximately ten thousand relevant DNA samples [25, 27] (Table 3).

Table 3. The number of identified bodies from the Ovčara mass grave by identification method

Identification method

Classical

Combination

Documents

Ante-mortem trauma

Teeth

Scars and tattoos

Jewellery

DNA analysis

Unidentified bodies

Total
Number (\%)

93 (46.5)

20 (10)

41 (20.5)

$10(5)$

17 (8.5)

4 (2)

$1(0.5)$

99 (49.5)

8 (4)

$200(100)$

The classical method yielded a final positive identification for $46.5 \%$ of the bodies. The dominant factors in the identification of $20.5 \%$ of the victims were personal documents found next to the body. Dental and medical records accelerated the identification of $13.5 \%$ of the bodies and a few were identified through special features and jewellery. Combining comparative elements proved successful in $10 \%$ of the cases. DNA analysis has been used to identify $49.5 \%$ of the bodies since 2000 . Only $4 \%$ of the exhumed human remains remain unidentified, due to the absence of material required for any methods [25, 27].

\section{Expert and scientific evidence from the Ovčara mass grave}

Expert and scientific evidence used in ICTY trials were place of death, time of death, number of victims, socio-demographic data, manner and cause of death, and identity of the victims [27].

\section{Evidence of place and time of death}

The findings on the existence of a mass grave presented in the "Report on the Preliminary Investigation of a Mass Grave Site near Vukovar in the former Yugoslavia” were accepted, along with other pieces of evidence, as murder indictment evidence against Mrkšić et al., corroborating the statement of a Prosecution witness, that the gravesite coincided with the site where an excavator was used to dig a large pit in the afternoon of 20 November 1991 $[1,41]$.

\section{Evidence of manner and cause of death}

An integral part of the murder charges was a report by international experts, containing a summary of findings from the examination of the bodies and established data on biological features and cause and manner of death, supplemented by “Autopsy Reports”. For 
$95 \%$ of the 200 exhumed victims, the cause of death was one or more gunshot wounds to vital parts of the body; the body of one woman contained 25 gunshot wounds and entry and exit wounds in the skull were found in 32 people, which is key evidence of a conscious intent to kill [24]. Traces of ante-mortem trauma were found in 86 victims. The autopsy could not determine the exact cause of death of 5 people, as the death most likely occurred due to gunshot wounds of soft tissues, which were invisible due to the condition in which the body was found [1].

\section{Evidence of age}

The average age of Ovčara victims at the time of death was 32.5 years; $80.5 \%$ of the victims were under 40 years of age and three were minors. The age of the youngest victim from Ovčara was 16 years and that of the oldest victim was 72 years [1, 24].

\section{Ballistic evidence}

The data on the number of projectiles found near or inside the bodies testifies to the fact that the death of the prisoners was the only, premeditated intent. More specifically, 540 different projectiles were removed from the bodies during autopsy and more than 1500 were found inside the grave [24]. Ballistic expert reports, commissioned by the ICTY and processed in Maryland, USA, concluded that the shell casings and projectiles retrieved from the Ovčara mass grave were of various calibres, mostly $7.62 \times 39 \mathrm{~mm}$ rifle ammunition and $7.62 \times 25 \mathrm{~mm}$ and $7.65 \times 17 \mathrm{~mm}$ calibre pistol ammunition, fired from 18 different types of weapons, including a Kalashnikov rifle, an M-56 automatic rifle, a Scorpion pistol, and a Heckler automatic pistol [24, 25].

\section{Evidence of victim classification}

The indictment for crimes against humanity was corroborated, among other evidence, by the discovery of bodies in civilian clothes, including women and children. Additionally, traces of medical treatment and supplies, such as crutches, bandages, plaster, catheters, etc., were also found, indicating that the executed were wounded. Hospital workwear and white clogs indicated that some of the executed were hospital staff [28, 39]. This evidence challenged the claim of the accused, that the persons buried in the mass grave were on an equal footing with the executors [39].

\section{Identification methods}

Anthropological methods revealed that the grave contained 198 male and 2 female bodies, 192 of which were identified, 93 by the classical identification method of feature recognition, and 99 by DNA analysis [1,27]. Although identification is not the only goal in forensic research, it proved to be key evidence in establishing the victim categorization findings for ICTY purposes in the case of the Ovčara mass grave. Specifically, it was important to establish the identity of the victims thrown into the grave because witness statements, corroborated by the list of missing wounded, civilians, and hospital staff from Vukovar Hospital, were a crucial part of the indictment against those responsible for the crime [9]. The final identification confirmed that out of 264 names on the list of missing persons 
from Vukovar Hospital, 194 were identified as victims exhumed from the Ovčara mass grave [9, 42] (Table 4).

Table 4. Summary of evidence from the Ovčara mass grave

\begin{tabular}{ll} 
Feature & Finding (number, $\%)$ \\
Grave type & Primary \\
Number of exhumed bodies & 200 \\
Bodies processed by forensic methods & $100 \%$ \\
Sex & female: 2, male: 198 \\
Age & \\
$16-20$ & $(10)$ \\
$21-30$ & $(38.5)$ \\
$31-40$ & $32)$ \\
$41-50$ & $(13)$ \\
$51-60$ & $4.5)$ \\
other & $(2)$ \\
Cause of death & firearm trauma: $195(95)$ \\
& other: 5 (5) \\
Manner of death & homicide: $(100)$ \\
Place of death & Ovčara farmland \\
Time of death & $20 / 21$ November 1991 \\
Positive identification & total: $192(96)$ \\
classical method: $93(46.5)$ \\
Unknown & DNA analysis: $99(49.5)$ \\
National and religious affiliation & 8 (4) \\
Victim classification & Croatian Catholic \\
& 86 injured (43) \\
& 2 women (1) \\
& 3 minors $(1.5)$ \\
& 20 medical staff $(10)$ \\
other (44.5) \\
\hline
\end{tabular}

\section{International criminal tribunal for the former Yugoslavia (ICTY)}

In May 1993, in response to mass crimes committed in the former SFRY, the UN Security Council, under Resolution 827, established the ICTY to prosecute individuals responsible for serious violations of humanitarian law in former Yugoslavia since 1991 [43].

The indictments alleged grave breaches of the Geneva Conventions, genocide, a crime against humanity, and war crime, committed since 1991 in former Yugoslavia [44]. The ICTY aimed to bring perpetrators responsible for these crimes to justice, establish peace in the warring countries to prevent the occurrence of further crimes, and administer justice for the victims [43].

The establishment of the court was prompted by reports of horrific crimes, thousands of killed and wounded, and hundreds of thousands exiled in Croatia and Bosnia and Herzegovina. Less than a year after the outbreak of Serbian aggression against Croatia, bringing large-scale destruction and claiming thousands of victims, the war spread to the Republic of Bosnia and Herzegovina, with its majority population composed of three national groups - Bosnian Muslims, Serbs, and Croats [45]. The first trial before the ICTY was held in May 1996, for crimes committed during 1992 in the Omarska war camp, which imprisoned thousands of Bosnian Muslims and Croats [46]. During its twenty-four-year 
run, the ICTY indicted 161 individuals, 90 of whom were sentenced, including for genocide. This was the first such sentence ever pronounced in Europe. 18 were acquitted, 20 had their indictments withdrawn, 37 were dropped due to the death of the accused, and 13 were referred to national jurisdictions [47].

Indictments filed for crimes committed in the Republic of Croatia included those involving Vukovar Hospital and the Ovčara mass grave, the siege and attack on Dubrovnik, and persecution and other crimes against Croats in the so-called Republic of Serbian Krajina [46].

Documents filed to the ICTY and used as evidence in criminal proceedings are the product of cooperation between international forensic scientists and participants in the investigation of the Ovčara mass grave [1]. Numerous reports, analyses, photographs, audio and video recordings, as well as testimonies by forensic experts have significantly contributed to the perception of these events and confirmed or refuted various testimonies in lengthy trials [9]. During the trials, the forensic findings were interpreted by several international and domestic forensic experts. One of the experts on the Croatian side was the professor of forensic medicine and representative of the Croatian Commission on Detainees and Missing Persons, Prof. D. Strinović, PhD, who, as an observer, supervised the exhumation of the Ovčara mass grave near Vukovar - the site of the first major war crime in Europe since World War II [1]. As an expert witness, he testified in five international trials before the ICTY, with an emphasis on the trial of Miroslav Radić, Veselin Šljivančanin, and Mile Mrkšić, known as the "Vukovar Three", for the mass execution of 200 civilians and wounded at Ovčara [1].

In 1998, Dr Clyde Snow, an anthropologist and associate of the American Academy of Forensic Sciences, interpreted the forensic findings from the investigation of the Ovčara mass grave in the case against Slavko Dokmanović, who was at the time president of the Vukovar Municipal Assembly [22].

Before the ICTY, four people were charged with flagrant violation of humanitarian law, torture, and the death of 200 people on grounds of command and individual responsibility, as well as participating in a joint criminal enterprise, three of whom were senior YPA officers [9]. After years of trials, the accused former Serbian YPA commander Mile Mrkšić, who later committed suicide in a Portuguese prison, was sentenced to 20 years in prison for murder, torture, and cruel treatment. Major Veselin Šljivančanin was convicted of torture but acquitted of murder charges and sentenced to 10 years in prison. After serving $2 / 3$ of his sentence, he was released in 2011 [28]. Former YPA officer Miroslav Radić was acquitted [28] and Slavko Dokmanović, Mayor of occupied Vukovar, committed suicide before his verdict [48].

The ICTY Prosecutor's Office referred the indictments of direct perpetrators of war crimes in Ovčara to the War Crimes Court in Belgrade. 24 people were charged with war crimes against prisoners at the Ovčara farmland, 2 of whom were repentant witnesses, 9 were convicted of capturing, abusing, and killing 200 prisoners of war, 3 died, and the rest were acquitted.

The following were convicted in trial proceedings:

- Miroljub Vujović, Stanko Vujanović, Predrag Milojević, to 20 years in prison; 
- Damir Sireta and Ivan Atanasijević, to 15 years in prison;

- Nada Kalaba, to 11 years in prison;

- Miroslav Đanković, Saša Radak and Goran Mugoša, to 5 years in prison [49].

\section{Comment}

The court proceedings on the massacre at Ovčara, the first major war crime in Europe postWorld War II, confirmed the basic biological characteristics of victims and cause of death for 195 persons on grounds of scientifically irrefutable evidence from a forensic analysis of the victims from the mass grave [27]. Despite the allegations of brutal torture from the statements of surviving witnesses, soft tissue injuries from blunt force and weapons other than firearms could not be proven in most cases. Extensive decay of the bodies - a consequence of a four-year delay caused by the Serbian authorities preventing the exhumation as well as damage from physical force during exhumation - hampered the identification of peri-mortem injuries. Firearm traumas, which leave visible marks on the bones, proved crucial in determining the cause of death. Although the exact number and type of injuries will never be determined with certainty, the sheer number of gunshot wounds in the bodies, especially to the back of the head, is a clear indicator of the act of execution.

The employment of various scientific disciplines - forensic archaeology, anthropology, odontology, and forensic medicine, as well as the then newly emerging method of DNA analysis - and the ante-mortem database which was the product of cooperation between Dr Snow and the Croatian authorities, greatly facilitated identification. This, alongside other forensic findings, ultimately proved crucial in determining the status of the victims who were identified as the persons who disappeared from Vukovar Hospital in November 1991, i.e., the wounded and prisoners who were not involved in the fighting at the time and could, therefore, not be considered legitimate military targets [1]. Findings confirming that the victims of the mass murder were unarmed Croatian Catholics were used to corroborate the indictment for ethnic cleansing and crimes against humanity [25]. The YPA involvement in the premeditated murder at Ovčara was proven by the fact that a YPA commander prevented international organizations from entering the hospital, organized the forced removal of prisoners in military buses, permitted the digging of the grave, and then ordered the withdrawal of YPA soldiers from Ovčara, leaving the Croatian prisoners at the mercy of hostile members of the Serbian territorial defence and paramilitary forces [28]. Certain omissions admittedly occurred during the investigation of the Ovčara mass grave site, such as the hasty exhumation that resulted in damage to the skeletal remains, insufficient photographic documentation, and cases of biased descriptions of the type and place of trauma [26]; nevertheless, the international forensic investigation significantly contributed to elucidating the crime committed at Ovčara on 20/21 November 1991. Forensic research not only contributed to the reconstruction of the course and manner of crimes and thus significantly facilitated the identification of perpetrators but also enabled the identification of the victims and provided their families with knowledge about their fate and the prospect of a dignified burial. 
The scores of hidden victims of mass human rights violations are a common denominator of all armed conflicts; the irrefutable scientific evidence resulting from the application of forensic sciences in the investigation of these crimes may, therefore, assist the legal, humanitarian, historical, and preventive needs of the international community in future conflicts. Although forensics played a noted role during the Nuremberg and Tokyo trials for World War II crimes, it was its contribution to the investigation of crimes in the former Yugoslavia and Rwanda in the early 1990s that prompted the international community to increase its application in war crime investigations worldwide [50]. This is evinced by the growing number of forensic teams as well as the ease of access to material resources that are necessary for their work. In more recent years, the findings of forensic experts have been instrumental in providing evidence of serious crimes committed in Guatemala and Cambodia [51, 52].

Ongoing armed conflicts at crime investigation sites as well as the obstruction of investigations by national authorities have been aggravating circumstances in the conduct of extensive forensic investigations, as was the case in the investigation of the Ovčara mass grave. From a legal and forensic perspective, a mitigating circumstance in the investigation of the Ovčara mass grave was the fact that the investigation focused on a single crime, namely, the murder of 200 people in the same location, unlike many other secondary and tertiary mass and individual graves in the former Yugoslavia and worldwide. All key evidence was recovered from the primary, uncontaminated gravesite, where the victims were killed and then buried.

In the case of exhumation and post-mortem examination of human remains, there is a need to establish uniform scientific and ethical standards and protocols to facilitate simultaneous utilization of forensic findings for both legal and humanitarian ends. In addition to providing access to material resources and ensuring the safety of forensic experts, the international community needs to exert more efforts to train national forensic teams and resolutely demand a forensic analysis of all victims of human rights violations.

Provenance: Submitted. The article is based on the master's thesis by Helena Ekštajn, entitled "The Role of Forensic Research in the Processing of War Crimes - Case-study of the Ovčara Mass Grave”, as the original author of this article at the Split University Department of Forensic Sciences. The photos used herein were taken from "The Investigator: Demons of the Balkan War” by Vladimir Dzuro, with the permission of the University of Nebraska Press and documentation provided by the Directorate on Detainees and Missing Persons of the Ministry of Croatian Veterans.

Peer review: Externally peer reviewed.

Received: 11 December 2020 / Accepted: 19 April 2021 / Published online: 9 July 2021.

Acknowledgements: The authors wish to thank Boris Dumenčić, PhD, MD, Head of the Department of Forensic Medicine at the Osijek Clinical Hospital Centre, for his assistance in developing the concept for this paper. We would also like to thank State Secretary at the Ministry of Croatian Veterans, Stjepan Sučić, who approved access to official documents and cooperation with an employee at the Directorate on Detainees and Missing Persons, Ana Filko, who generously shared her knowledge on this subject with us. We particularly wish to thank Ante Lozina, MSc of Law for contextualising the historical events and to Prof. Matko Marušić, PhD, whose unconditional support was the impetus for the creation of this scientific paper. 
Funding: This research received no specific grant from any funding agency in public, commercial or not-for-profit sectors.

Authorship declaration: All authors conceived and designed research, HE conducted data acquisition, all authors analyzed and interpreted data, HE drafted the manuscript, all authors critically revised the manuscript for important intellectual content, all authors approved the version to be published, all authors agree to be accountable for all aspects of the work.

Competing interests: The authors completed the ICMJE Unified Competing Interest form (available upon request from the corresponding author), and declare no conflicts of interest.

\section{ORCID}

Helena Ekštajn (1) https://orcid.org/0000-0002-9770-2468

Ivana Kružić (i) https://orcid.org/0000-0002-2285-2189

Željana Bašić (ㅇ https://orcid.org/0000-0002-8327-1978

\section{References}

1. ICTY Court Records [Internet]. The Hague: ICTY; 2006 - Mrkšić et al. (IT-95-13/1): Transcript of the Testimony of Dr. Strinović; [cited 2020, 28 September]; [about 197 pp.]. Available from: https://www.icty.org/x/cases/mrksic/trans/en/060523IT.htm.

2. ICTY Court Records [Internet]. The Hague: ICTY; 1993 - What is the Former Yugoslavia; [cited 2020, 20 September]; [about 2 pp.]. Accessible at https://www.icty.org/en/about/what-formeryugoslavia/conflicts.

3. Perković Paloš A. The Croatian War of Independence (1991-1995), In: Marušić M, editor. Croatia: Past, Present and Future Perspectives. New York: Nova Publishers; 2020. p. 267-294.

4. Sučić S, Živić D. Vukovar - hrvatska baština i perspektive razvoja: Značenje vukovarske bitke u stvaranju i obrani hrvatske države. Ivo Pilar Institute of Social Sciences. 2007:73-96.

5. United Nations Security Council [Internet]. The Hague: ICTY; 1994 - Letter dated 24 May 1994 from the Secretary-General to the President of the Security Council: Annex I: Summary of the Report of the Special Rapporteur on Extrajudicial, Summary or Arbitrary Executions on his Mission to Investigate Allegations of Mass Graves from 15 to 20 December 1992; [cited 2020, 3 October]; [about 84 pp]. Available from: https://www.icty.org/x/file/About/OTP/un_commission_ of_experts_report1994_en.pdf.

6. Ministry of Croatian Veterans, Directorate on Detainees and Missing Persons. Knjiga osoba nestalih na području Republike Hrvatske. Zagreb: Ministry of Croatian Veterans; 2015.

7. Grujić I, Bilić V. Zatočeni, nestali i masovne grobnice: žrtve i dokazi zločina. IN: Živić D, Žebec I, editors. Demografski kontekst i sociokulturne posljedice hrvatskog Domovinskog rata. Vol. 35. Zagreb - Vukovar: Ivo Pilar Institute of Social Sciences. 2009.

8. Živić D. Promjene narodosnog sastava stanovništva gradskih naselja Istočne Hrvatske 1910. 1991. godine: Promjene etničke strukture gradskih naselja od 1910. do 1991. godine. Migracijske teme. 1998;14(1-2):99-127.

9. ICTY Court Records [Internet]. The Hague: ICTY; 2009 - Prosecutor V. Mile Mrkšić, Veselin Šljivančanin: Whether Šljivančanin Directed the Evacuation Operation at the Vukovar Hospital; [cited 2020, 13 October]; [about 195 pp]. Available from: https://www.icty.org/x/cases/mrksic/ acjug/en/090505.pdf.

10. ICTY Court Records [Internet]. The Hague: ICTY; 2006 - Transcript of Testimony, Dr. Vesna Bosanac; [cited 2020, 11 October]; [about 86 pp]. Available from: https://www.icty.org/x/cases/ mrksic/trans/en/060404IT.htm.

11. Marušić M. (ed.). Medical Testimony of the Vukovar Tragedy. Croatian Medical Journal. Zagreb: 1991.

12. Cox M, Flavel A, Hanson I. The Scientific Investigation of Mass Graves: Towards Protocols and Standard Operating Procedures. 3rd ed. New York: Cambridge University Press; 2008. 
13. Prahlow JA. Forensic Pathology for Police, Death Investigators, Attorneys, and Forensic Scientists: Introduction to Forensic Sciences. 1st ed. USA: Humana Press; 2010.

14. Okoye MI, M.D., J.D., Wecht CH, M.D., J.D. Forensic Investigation and Management of Mass Disasters: Current Trends in Forensic Investigations of Human Rights Abuse: Human Identification of Mass Graves. Tucson: Lawyers \& Judges Publishing Company, Inc; 2007.

15. Ferllini R. The Development of Human Rights Investigations since 1945. Science \& Justice. 2003; 43(4):219-224

16. Cox M. A Multidisciplinary Approach to the Investigation of Crimes against Humanity, War Crimes and Genocide: the Inforce Foundation. Science \& Justice. 2003;43(4):225-27.

17. Vollen L. All That Remains: Identifying the Victims of the Srebrenica Massacre. Cambridge Quarterly of Healthcare Ethics. 2001;10(3):336-340.

18. United Nations Human Rights Council [Internet]. Geneva; 1993 - Summary of the Report of the Special Rapporteur on Extrajudicial, Summary or Arbitrary Executions on his Mission to Investigate Allegations of Mass Graves from 15 to 20 December 1992; [cited 2020, 16 October]; [about 78 pp]. Available from: https://digitallibrary.un.org/record/226088.

19. Physicians for Human Rights [Internet]. Boston: Mass Grave Investigations: Mass Crimes in Croatia; c1991 [cited 2020, 19 October] [about 2 screens] Available from: https://phr.org/issues/ investigating-deaths-and-mass-atrocities/investigating-mass-crimes-for-prosecutions/masscrimes-in-croatia-vukovar-investigation-1991/.

20. International Commission on Missing Persons [Internet]. The Hague: Western Balkans; c2020 [cited 2020, 25 October]; [about 4 screens] Available from: https://www.icmp.int/where-wework/europe/western-balkans/.

21. International Commission on Missing Persons [Internet]. The Hague: About Us; c2020 [cited 2020, 25 October]; [about 2 screens] Available from: https://www.icmp.int/about-us/.

22. ICTY Court Records [Internet]. The Hague: ICTY; 1998 - Transcript of Testimony, Dr. Clyde Snow; [cited 2020, 23 October]; [about 83 pp]. Available from: https:/www.icty.org/x/cases/ dokmanovic/trans/en/980317ed.htm.

23. United Nations Digital Library [Internet]. New York: UN Security Council; 1992 - Human rights questions: Human rights situations and reports of the Special Rapporteurs and representatives about situation of human rights in the territory of the former Yugoslavia; [cited 2020, 19 October]; [about 40 pp]. Available from: https://digitallibrary.un.org/record/154683.

24. ICTY Court Records [Internet]. The Hague: ICTY; 2008 - Transcript of Testimony, Dr. Davor Strinović; [cited 2020, 27 October]; [about 100 pp]. Available from: https://www.icty.org/x/cases/ seselj/trans/en/081111ED.htm.

25. ICTY Court Records [Internet]. The Hague: ICTY; 2003 - Transcript of Testimony, Dr. Davor Strinović; [cited 2020, 29 October]; [about 90 pp]. Available from: https:/www.icty.org/x/cases/ slobodan_milosevic/trans/en/030314IT.htm.

26. ICTY Court Records [Internet]. The Hague: ICTY; 2012 - Transcript of Testimony, Dr. William Haglund; [cited 2020, 19 October]; [about 85 pp]. Available from: https:/www.icty.org/x/cases/ karadzic/trans/en/120131IT.htm.

27. Milewski YI, M.D. Analysis of Pathologic Findings at Autopsy of the Individuals Exhumed from the Ovčara Grave near Vukovar, Croatia. New York, USA. 1988.

28. ICTY Court Records [Internet]. The Hague: ICTY; 2007 - Trial Chamber Judgement II; [cited 2020, 17 October]; [about 331 pp]. Available from: https:/www.icty.org/x/cases/mrksic/tjug/ en/070927.pdf.

29. Filko A. Ovčara - siva zona međunarodne zajednice (1992. - 1994.). Scrinia slavonica. 2020;20:337-72.

30. ICTY Court Records [Internet]. The Hague: ICTY; 2006 - Transcript of the Testimony of a Protected Witness P-011; [cited 2020, 15 October]; [about 48 pp]. Available from: https://www. icty.org/x/cases/mrksic/trans/en/060308ED.htm.

31. ICTY Court Records [Internet]. The Hague: ICTY; 1997 - Trial Chamber Judgement; [cited 2020, 16 October]; [about 12 pp]. Available from: https://www.icty.org/x/cases/mrksic/ind/en/mrk2ai1971202e.pdf.

32. Mazowiecki T. Izvještaji 1992. - 1995. Tuzla: Univerzitet u Tuzli i Istraživačko-dokumentacioni centar Sarajevo; 2007. 
33. ICTY Court Records [Internet]. The Hague: ICTY; 2013 - Public Version of the UNPROFOR Telegram by Satish Nambiaro Blanci, UNOG Geneva, Concerning the Alleged Mass Grave at Ovčara of 3 November 1992, Attached: Testimony (IT-04-75); [cited 2020, 16 October]; [about 98 pp]. Available from: https://www.icty.org/x/cases/hadzic/trans/en/130619ED.htm.

34. UN Security Council [Internet]. The Hague: ICTY; 1994 - Final Report of the Commission of Experts Established Pursuant to Security Council Resolution 780 (1992): Annex X.A. Mass Graves - Ovčara, near Vukovar, UNPA Sector East; [cited 2020, 23 October]; [about $14 \mathrm{pp}$ ]. Available from: https://intersentia.com/en/fileuploader/download/index/ file/7ceaa77d79f3c63a3dfa7def12e953765c58308b2c0842549b/product/33615/.

35. Stover E. Medicine Under Siege in the Former Yugoslavia: 1991- 1995: The Vukovar Massacre. Boston etc. Physicians for Human Rights; 1996.

36. Dzuro V. The Investigator: Demons of the Balkan War. 3rd ed. Lincoln: Potomac Books; 2017.

37. ICTY Court Records. The Hague; 2010 - Case: Stanišić and Simatović (IT - 03-69); An article in The Washington Post Entitled "Serbs Accused of Mass Grave in Croatia” from January 26, 1993.

38. ICTY Court Records [Internet]. The Hague: ICTY; 2013 - Fax of the CIVPOL headquarters in Sector East at the CIVPOL headquarters in Zagreb dated 15 December 1992: Visit of the forensic team, response: mass grave - Ovčara, attached: Investigation report dated 24 October 1992; [cited 2020, 20 October]; [about 86 pp]. Available from: https://www.icty.org/x/cases/hadzic/ trans/en/130717IT.htm.

39. Stover E, Peress G. The Graves: Srebrenica and Vukovar. 1st ed. Zurich: Scalo; 1998.

40. Strinović D, Skavić J, Kostović I, Henigsberg N, Judas M, Clark D. Identification of War Victims in Croatia. Medicine, Science and the Law. 1994;34(3):207-12.

41. ICTY Court Records [Internet]. The Hague: ICTY; 2006 - Transcript of testimony of journalists Le Monde, Florence Hartmann; [cited 2020, 1 November]; [about 109 pp]. Available from: https:// www.icty.org/x/cases/mrksic/trans/en/060525ED.htm.

42. ICTY Court Records [Internet]. The Hague: ICTY; 2006 - Transcript of Testimony of Colonel Ivan Grujić; [cited 2020, 2 November]; [about 82 pp]. Available from: https://www.icty.org/x/cases/ mrksic/trans/en/060601ED.htm.

43. United Nations Digital Library [Internet]. New York: UN Security Council; 1993 - Resolution 827 (1993) / adopted by the Security Council at its 3217th meeting, on 25 May 1993; [cited 2020, 6 November]; [about 3 pp] Accessible from: https://www.icty.org/en/about/what-formeryugoslavia/conflicts.

44. ICTY Court Records [Internet]. The Hague: ICTY; 1993 - Mandate and Crimes under ICTY Jurisdiction; [cited 2020, 20 September]; [about 3 screens] Available from: https://www.icty.org/ en/about/tribunal/mandate-and-crimes-under-icty-jurisdiction.

45. ICTY Court Records [Internet]. The Hague: ICTY; 1993 - What is the Former Yugoslavia: The Conflicts; [cited 2020, 20 September]; [about 2 screens] Available from: https://www.icty.org/en/ about/what-former-yugoslavia/conflicts.

46. ICTY Court Records [Internet]. The Hague: ICTY; c1996 [cited 2020, 24 September]. The Tribunal's first trial: another step in the fulfilment of the Tribunal's mandate; [about 2 screens]. Available from: https://www.icty.org/en/press/tribunals-first-trial-another-step-fulfillment-tribunalsmandate.

47. ICTY Court Records [Internet]. The Hague: ICTY; c2019 [cited 2020, 25 September]. Key Figures of the Cases; [about 2 screens]. Available from: https://www.icty.org/en/cases/key-figures-cases.

48. ICTY Court Records [Internet]. The Hague: ICTY; c1998 [cited 2020, 26 October]. Accused Slavko Dokmanović found dead in his cell; [about 1 screen]. Available from: https://www.icty.org/en/ $\operatorname{sid} / 7658$.

49. Fond za humanitarno pravo. Izveštaj o suđenjima za ratne zločine u Srbiji: Pravosnažno okončani predmeti - predmet Ovčara. Belgrade: Fond za humanitarno pravo; 2019. p.146-55.

50. Stover E. In the Shadow of Nuremberg: Pursuing War Criminals in the Former Yugoslavia and Rwanda. Medicine \& Global Survival. 1995;2(3):140-46.

51. Oll Sese M., Burt J.M., Collardele C. Genocide in Guatemala: Rios Montt Guilty. In: Bernard A., editor. The trial proceedings: The expert reports: corroboration of the victim's testimonies and of Jose Efrain Rios Mont's responsibility. Paris, France: International Federation for Human Rights (FIDH); 2013. p. 14-16.

52. De Nike H.J., Quigley J., Robinson K. J. Genocide in Cambodia: Documents from the Trial of Pol Pot and Ieng Sary. Human Rights Quarterly. 2001;23(02):470-77. 